\title{
SINGLE SUBJECT RESEARCH: PEMBELAJARAN PERBANDINGAN SENILAI DAN BERBALIK NILAI BERPENDEKATAN CONTEXTUAL TEACHING AND LEARNING UNTUK SISWA SLOW LEARNER
}

\author{
Pratita Manikmaya, Rully Charitas Indra Prahmana \\ Universitas Ahmad Dahlan, Jl. Pramuka 42, Pandeyan, Umbulharjo, Yogyakarta, Indonesia \\ E-mail: rully.indra@mpmat.uad.ac.id
}

\begin{abstract}
Abstrak
Siswa Slow Learner sering kali mengalami kesulitan dalam memahami materi matematika, salah satunya materi perbandingan senilai dan berbalik nilai. Penelitian ini bertujuan untuk meningkatkan pemahaman siswa Slow Learner mengenai materi perbandingan senilai dan berbalik nilai dengan pendekatan Contextual Teaching and Learning (CTL). Subyek penelitian dalam penelitian ini berupa subyek tunggal yaitu siswa Slow Learner yang duduk di kelas VII SMP di kabupaten Bantul, Daerah Istimewa Yogyakarta. Penelitian ini menggunakan metode Single Subject Research dengan desain A-B. Data pada penelitian ini dikumpulkan melalui dokumentasi audio, foto, video, dan dokumentasi tertulis. Data kemudian dianalisis menggunakan analisis dalam kondisi dan analisis antar kondisi. Hasil penelitian menunjukan bahwa siswa memiliki skor rata-rata hasil belajar yaitu 32 sebelum diberikan intervensi dan memiliki skor ratarata 78 setelah diberikan intervensi berupa implementasi pembelajaran dengan pendekatan CTL. Hal ini menunjukan bahwa dengan menggunakan pendekatan CTL mampu meningkatkan pemahaman siswa Slow Learner dalam memahami materi perbandingan senilai dan berbalik nilai dan meminimalisir kesulitan belajar siswa Slow Learning selama kegiatan belajar-mengajar.
\end{abstract}

Kata Kunci: perbandingan senilai dan berbalik nilai, siswa slow learner, contextual teaching and learning, single subject research

\begin{abstract}
Slow Learner students often have difficulty understanding mathematics content, one of which is direct and inverse proportion. This study aims to improve the student's understanding of the direct and inverse proportion material using the Contextual Teaching and Learning (CTL) approach. The research subject in this study was a single subject, namely Slow Learner student who studied in seventh grade in one of the Junior High School in Bantul district, Yogyakarta Special Region. This study used the Single Subject Research method with an A-B design. Researchers collected the data in this study through audio documentation, photos, videos, and written documentation. The data were then analyzed using analysis in conditions and between conditions. The results showed that students had an average score of learning outcomes that was 32 before being given intervention and had an average score of 78 after being given an intervention to implement learning with the CTL approach. This result shows that using the CTL approach can improve the understanding of Slow Learner student in understanding the direct and inverse proportion and minimizing the learning difficulties of Slow Learning student during teaching and learning activities.
\end{abstract}

Keywords: direct and inverse proportion, slow learner student, contextual teaching and learning, single subject research 


\section{PENDAHULUAN}

Matematika merupakan mata pelajaran yang penting dipelajari oleh siswa (Elita, 2012). Sebagai mata pelajaran yang penting, matematika perlu diberikan kepada siswa guna membekali kemampuan sistematis, analitis, kreatif, kritis, dan berpikir logis (Muchlis, 2012). Oleh karena itu, matematika perlu dipelajari oleh siswa di sekolah dengan pemahaman konsep yang baik, sehingga kelak dapat membekali siswa dengan kemampuan matematis yang baik pula.

Selama ini, mata pelajaran matematika dianggap sebagai mata pelajaran yang menakutkan, sulit, dan membosankan (Abdillah \& Fitriana, 2019). Hal ini sebagaimana yang diungkapkan Utari (2013), yang menyatakan bahwa kesulitan belajar matematika siswa terletak pada kurangnya kemampuan siswa dalam berimajinasi, memahami serta mengerjakan dengan teliti permasalahan yang berkaitan dengan matematika. Dengan kata lain, matematika masih menjadi mata pelajaran yang dihindari oleh sebagian siswa karena kurangnya pemahaman siswa terhadap matematika itu sendiri.

Setiap siswa mempunyai kemampuan yang berbeda-beda dalam memahami materi pelajaran (Richardo, Abdullah, \& Yuherni, 2018). Kurangnya pemahaman siswa tersebut, salah satunya disebabkan oleh learning disability yang merupakan kelainan atau kesulitan yang membuat siswa merasa kesulitan untuk melakukan kegiatan belajar secara efektif (Arsjad, 2013). Faktor-faktor yang mempengaruhi kesulitan belajar siswa dibagi menjadi dua, yaitu faktor internal berupa minat, bakat, sikap, kebutuhan, motivasi, dan intelegensi, serta faktor eksternal berupa sekolah, guru, keluarga, dan masyarakat (Haryanti, 2002). Ini artinya, kurangnya pemahaman siswa dapat disebabkan karena kesulitan belajar pada siswa itu sendiri, baik dari faktor internal maupun eksternal.

Kesulitan belajar matematika ini juga dialami oleh siswa slow learner atau siswa yang lamban belajar. Siswa slow learner merupakan siswa dengan kemampuan belajar yang lambat, jika dibandingkan dengan siswa yang lain pada umumnya, sehingga siswa ini memerlukan waktu yang lebih banyak untuk memahami materi yang diberikan oleh guru (Harahap, 2017). Hal ini sebagaimana diungkapkan Rakhmawati (2017), yang menyatakan bahwa siswa slow learner merupakan siswa dengan hasil belajar dibawah rata-rata siswa pada umumnya.

Layanan perhatian khusus diperlukan untuk siswa slow learner, dikarenakan biasanya dalam belajar, siswa tersebut menghadapi sejumlah masalah, antara lain yaitu 
memiliki sesulitan dalam memahami konsep abstrak, motivasi belajar yang rendah, membutuhkan waktu yang sedikit lama untuk memahami materi, dan membutuhkan pengulangan materi (Maylina, 2014). Selain itu, Hidayat (2009) juga menjelaskan bahwa dibutuhkan strategi pembelajaran yang tepat untuk siswa slow learner dengan menyesuaikan kemampuan belajar siswa tersebut terhadap tujuan, alokasi waktu, penghargaan, tugas dan tindak lanjut dalam pembelajaran. Sejalan dengan hal tersebut, Saleh, Huriaty, dan Riadi (2017) mengungkapkan bahwa pembelajaran untuk siswa yang mengalami kesulitan belajar dapat dilakukan dalam beberapa tahapan yaitu kesiapan awal sebelum pembelajara, proses pelaksanaan pembelajaran, evaluasi, dan tindak lanjut. Di sisi lain, salah satu prasyarat pembelajaran untuk siswa slow learner adalah mengetahui kemampuan awal siswa yang kemudian dilanjutkan dengan perlakukan yang melibatkan partisipasi siswa tersebut (Hidayat, 2009).

Berdasarkan hasil observasi yang dilakukan peneliti pada tanggal 7 Oktober 2019 di salah satu Sekolah Menengah Pertama (SMP) di Bantul, Daerah Istimewa Yogyakarta, diperoleh hasil bahwa di sekolah tersebut terdapat siswa slow learner. Siswa tersebut berada di kelas VII G. Selanjutnya, hasil wawancara dengan guru mata pelajaran matematika diperoleh informasi bahwa siswa tersebut mengalami kesulitan dan lambat dalam menerima materi matematika yang disampaikan oleh guru. Salah satu materi matematika yang sulit dipahami oleh siswa tersebut adalah materi perbandingan senilai dan berbalik nilai. Oleh karena itu, penelitian ini bertujuan untuk mengetahui peningkatan kemampuan siswa slow learner dalam memahami materi perbandingan senilai dan berbalik nilai menggunakan pendekatan Contextual Teaching and Learning (CTL). Penggunaan pendekatan CTL dalam kegiatan belajar-mengajar, diketahui mampu meningkatkan kemampuan pemahaman matematis siswa pada siswa normal (Musyafa, dkk., 2020; Kurnia, 2020; Tamur, dkk., 2020). Namun, belum ditemukan penggunaan pendekatan ini pada siswa slow learner dalam upaya meningkatkan kemampuan matematis siswa tersebut. Harapannya hasil penelitian ini dapat menambah khazanah ilmu pengetahuan di bidang matematika mengenai pendekatan pembelajaran yang efektif untuk meningkatkan kemampuan pemahamaman matematika siswa slow learner.

\section{METODE PENELITIAN}

Metode penelitian yang digunakan dalam penelitian ini adalah metode Single Subject Research. Prahmana (2021) mendefinisikan Single Subject Research sebagai 
suatu metode penelitian eksperimen untuk melihat dan mengevaluasi suatu intervensi tertentu atas perilaku dari suatu subjek tunggal dengan penilaian yang dilakukan berulang-ulang dalam suatu waktu tertentu. Metode ini dipilih dikarenakan sangat efektif untuk mengevaluasi efek suatu perlakuan pada subyek tunggal yang sulit dilihat pada subyek kelompok (Harrera \& Kratochwill, 2015; Prahmana, 2021; Neuman \& McCorrnick, 1995). Adapun tujuan penelitian ini adalah untuk menyelidiki lebih lanjut mengenai kesulitan belajar siswa slow learner dan faktor-faktor yang mempengaruhi kesulitan belajar siswa dalam memahami materi matematika, sehingga nantinya dapat meningkatkan pemahaman matematis siswa.

Penelitian Single Subject Research berkaitan erat dengan modifikasi perilaku yaitu sebuah pendekatan ilmiah untuk memahami dan mengubah perilaku manusia guna mengatasi permasalahan mengenai perilakunya (Prahmana, 2021). Dalam proses modifikasi perilaku terdapat empat kegiatan, yaitu mengindentifikasi masalah, menentukan level perilaku, memberikan intervensi, dan menindaklanjuti (Sunanto, Takeuchi, \& Nakata, 2006). Pada desain Single Subject Research, pengukuran variabel terkait atau target behavior dilakukan berulang-ulang dengan periode tertentu, misalnya perminggu, perhari atau perjam.

Desain penelitian yang digunakan dalam penelitian ini yaitu desain A-B yang merupakan desain dasar dalam penelitian Single Subject Research, pada desain ini peneliti mengumpulkan data tentang subyek dalam dua kondisi atau fase yaitu fase baseline dan fase intervensi. Pada penelitian Single Subject Research ini perilaku subyek dibandingkan dalam kondisi yang berbeda (Sunanto, Takeuchi \& Nakata, 2021). Kondisi berbeda tersebut merupakan kondisi baseline atau kondisi subyek ketika belum diberikan intervensi dan kondisi eksperimen, yaitu kondisi subyek setelah diberikan intervensi atau perlakuan. Dipilih desain ini karena fase baseline dan intervensi hanya dilakukan satu kali atau tidak ada pengulangan. Hal tersebut mengingat adanya keterbatasan penelitian baik dari segi tenaga, waktu, pikiran, dan biaya, sehingga desain A-B ini yang paling memungkinkan untuk dilakukan oleh peneliti.

Pada penelitian ini data dikumpulkan melalui audio, foto, video, dan dokumentasi tertulis. Audio, foto, dan video digunakan untuk mendeskripsikan kegiatan pembelajaran pada tahap intervensi. Dokumen tertulis berupa lembar tes tertulis digunakan untuk mengetahui perubahan hasil pembelajaran pada fase baseline dan pada fase intervensi. 
Data yang sudah dikumpulkan kemudian dianalisis menggunakan analisis visual dengan data grafik untuk menginterpretasikan efek dari suatu perlakuan. Selanjutnya, analisis data yang digunakan dalam penelitian ini yaitu analisis visual dalam kondisi atau analisis data dalam satu kondisi dan analisis visual antar kondisi atau analisis data dalam beberapa kondisi.

\section{HASIL DAN PEMBAHASAN}

Penelitian Single Subject Research ini dilakukan di salah satu Sekolah Menengah Pertama (SMP) di kabupaten Bantul, Daerah Istimewa Yogyakarta. Subyek tunggal dalam penelitian ini adalah siswa Slow Learner yang duduk di kelas VII. Berdasarkan hasil observasi, wawancara dengan guru, tes IQ, dan hasil Ujian Tengah Semester (UTS), diketahui bahwa mengalami kesulitan belajar dalam memahami materi matematika salah satunya materi perbandingan senilai dan berbalik nilai. Kesulitan belajar siswa dapat disebabkan oleh beberapa faktor antara lain faktor internal yaitu faktor fisiologi dan psikologi serta faktor eksternal yaitu faktor non sosial. Hal ini sejalan dengan Amir \& Risnawati (2015) yang mengatakan bahwa faktor yang dapat mempengaruhi kesulitan belajar siswa bukan hanya dipengaruhi oleh hasil belajar siswa, tetapi ada beberapa faktor lain yaitu faktor internal dan faktor eksternal.

Pada faktor fisiologi, siswa tidak memiliki gangguan fisik dan kondisinya sama dengan siswa lainnya. Namun, siswa sedikit memiliki kendala dalam berbicara atau cenderung gagap, sehingga sedikit menghalangi dalam berkomunikasi. Kemudian dalam kaitannya dengan bersosialisasi, siswa tidak memiliki permasalahan dalam bersosialisasi meskipun sedikit memiliki kendala komunikasi, tetapi siswa tersebut mampu bersosialisasi dengan baik, mudah bergaul dan tidak menutup diri dengan temantemannya. Hanya saja, ketika di dalam kelas, siswa tersebut cenderung pasif.

Secara psikologis, peneliti mencoba memberikan beberapa pertanyaan untuk menggali hal-hal yang berkaitan dengan psikologis siswa. Hasil yang diperoleh yaitu siswa memiliki semangat yang cukup dalam pembelajaran, motivasi siswa juga cenderung baik, dan selalu berusaha untuk mengasah kemampuannya dengan mencatat apa yang disampaikan oleh guru dan belajar bersama dengan guru les ketika di rumah. Namun, ketika pembelajaran dikelas guru meminta siswa tersebut maju untuk presentasi atau mengerjakan soal, siswa tersebut cenderung pasif dan sering kurang konsentrasi. 
Ketika ada teman yang melakukan sesuatu hal yang dapat menarik perhatian siswa tersebut, maka konsentrasi siswa tersebut mudah teralihkan. Misalnya ketika teman lain mengajak berbicara saat pembelajaran, maka konsentrasi siswa menjadi teralihkan ke pembicaraan temannya tersebut.

Selanjutnya faktor eksternal non sosial, yaitu ketersediaan fasilitas media pembelajaran di sekolah masih minim. Dalam pembelajaran matematika, media pembelajaran sebenarnya penting untuk menjembatani siswa dalam memahami hal yang konkret menuju hal yang abstrak (Harahap, 2019). Selama ini, di sekolah tersebut guru memberikan pembelajaran dengan memberikan teori matematika dengan bantuan buku. Kemudian siswa mendengarkan, mencatat dan mengerjakan soal.

Selain itu, berdasarkan hasil observasi terhadap subyek, diketahui bahwa siswa mengalami beberapa kesulitan dan kekeliruan pada pemahaman mengenai simbol, nilai tempat, kesalahan perhitungan, dan sering kali kurang teliti dalam mengerjakan soal. Hal ini sesuai, sebagaimana diungkapkan oleh Amir dan Risnawati (2015) bahwa kesulitan belajar merupakan gangguan proses belajar untuk satu atau beberapa bidang yang dapat diketahui melalui pengamatan khusus kepada siswa yang bersangkutan. Dalam pembelajaran matematika, biasanya siswa mengalami beberapa kekeliruan dikarenakan kurangnya pemahaman mengenai simbol, nilai tempat, dan proses dalam memahami materi atau dalam mengerjakan soal matematika (Amir \& Risnawati, 2015).

Berdasarkan identifikasi kesulitan belajar siswa tersebut kemudian memberikan perlakukan berupa pengimplementasian pembelajaran perbandingan senilai dan berbalik nilai menggunakan pendekatan contextual teaching and learning. Implementasi pembelajaran tersebut, dilaksanakan selama delapan sesi yang terdiri dari empat sesi fase baseline dan empat sesi fase intervensi, dengan waktu per sesi yaitu selama 45 menit. Pada penelitian ini fase baseline bertujuan untuk mengetahui kemampuan awal siswa sebelum diberi perlakukan dan fase intervensi bertujuan untuk mengetahui kemampuan awal siswa setelah diberikan perlakuan. Pada fase intervensi peneliti memberikan perlakukan berupa penerapan pendekatan contextual teaching and learning yang kemudian dilanjutkan dengan memberikan soal evaluasi untuk mengetahui kemampuan siswa setelah diberikan perlakuan. Adapun salah satu jawaban soal evaluasi siswa dapat dilihat pada Gambar 1. 


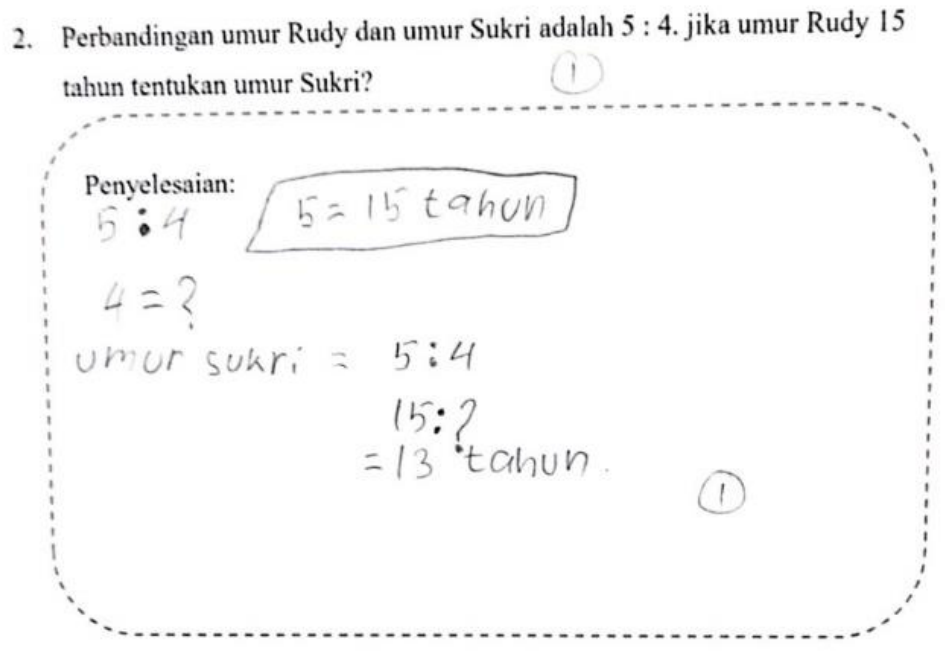

Gambar 1. Jawaban siswa pada Fase Baseline

Selanjutnya pada pada tahap intervensi, peneliti memberikan perlakukan dengan mengimplementasikan pembelajaran perbandingan senilai dan berbalik nilai menggunakan pendekatan contextual teaching and learning berupa soal dan contoh yang berhubungan dengan lingkungan sekitar siswa. Sehingga siswa dapat dengan mudah membayangkan atau merefleksikan materi matematika dalam kehidupan nyata di sekitar siswa. Selanjutnya siswa kemudian diminta untuk menyebutkan contoh lain dari konsep materi yang sudah dipahami siswa. Setelah memberikan beberapa contoh yang berkaitan dengan dunia nyata disekitar siswa, peneliti kemudian memberikan soal mengenai materi tersebut untuk mengetahui kemampuan siswa pasca intervensi diberikan. Adapun salah satu contoh hasil jawaban siswa pasca intervensi dapat dilihat pada Gambar 2.

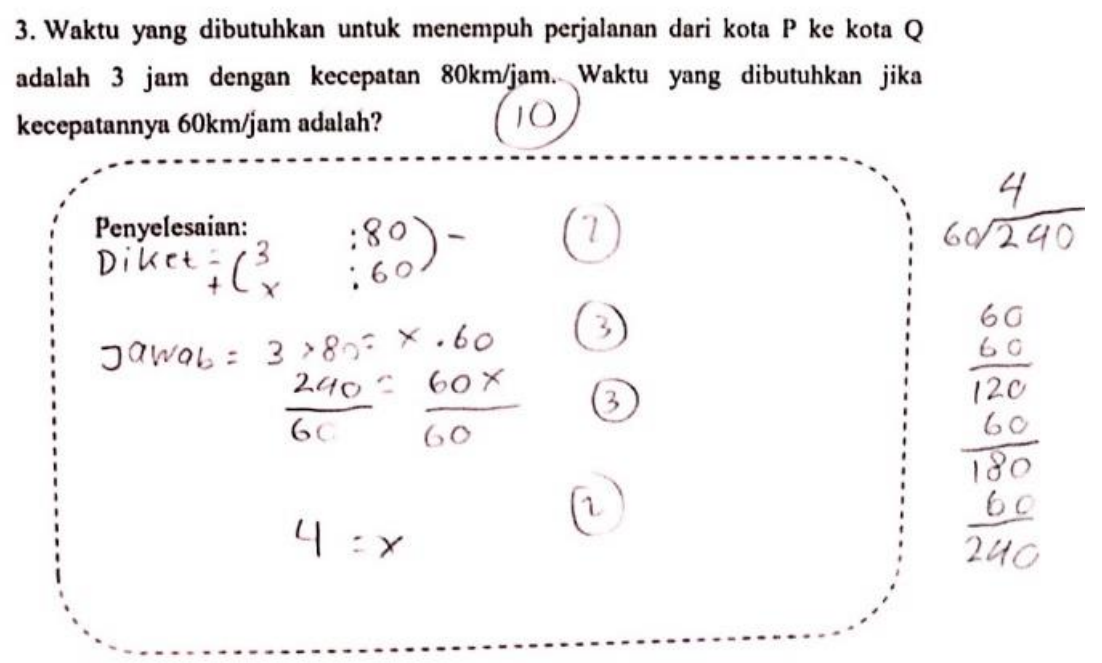

Gambar 2. Jawaban siswa pada Fase Intervensi 
Setelah pengimplementasian pembelajaran dilakukan, semua data kemudian dikumpulkan. Pengumpulan data tersebut dikumpulkan mulai dari fase baseline hingga fase intervensi, kemudian dianalisis. Adapun data yang dikumpulkan yaitu berupa hasil evaluasi yang dapat dilihat pada Tabel 1.

Tabel 1. Hasil evaluasi siswa

\begin{tabular}{ccc}
\hline Fase & Tanggal Pelaksanaan & Skor \\
\hline Baseline & 20 Januari 2020 & 34 \\
& 21 Januari 2020 & 30 \\
& 24 Januari 2020 & 30 \\
& 25 Januari 2020 & 34 \\
Intervensi & 27 Januari 2020 & 74 \\
& 28 Januari 2020 & 80 \\
& 31 Januari 2020 & 76 \\
& 01 Februari 2020 & 82 \\
\hline
\end{tabular}

Tabel 1 menunjukan hasil evaluasi siswa pada fase baseline dan fase intervensi atau pada fase sebelum diberikan perlakukan dengan sesuah diberikan perlakukan. Hasil tersebut menunjukkan bahwa terjadi kenaikan skor siswa dari fase baseline yang rata-rata skornya 32, naik di fase intervensi menjadi rata-rata skornya 78. Dapat dilihat bahwa intervensi memberikan perubahan yang signifikan terhadap hasil belajar siswa. Secara grafik hasil evaluasi belajar siswa tersebut dapat dilihat pada Gambar 3.

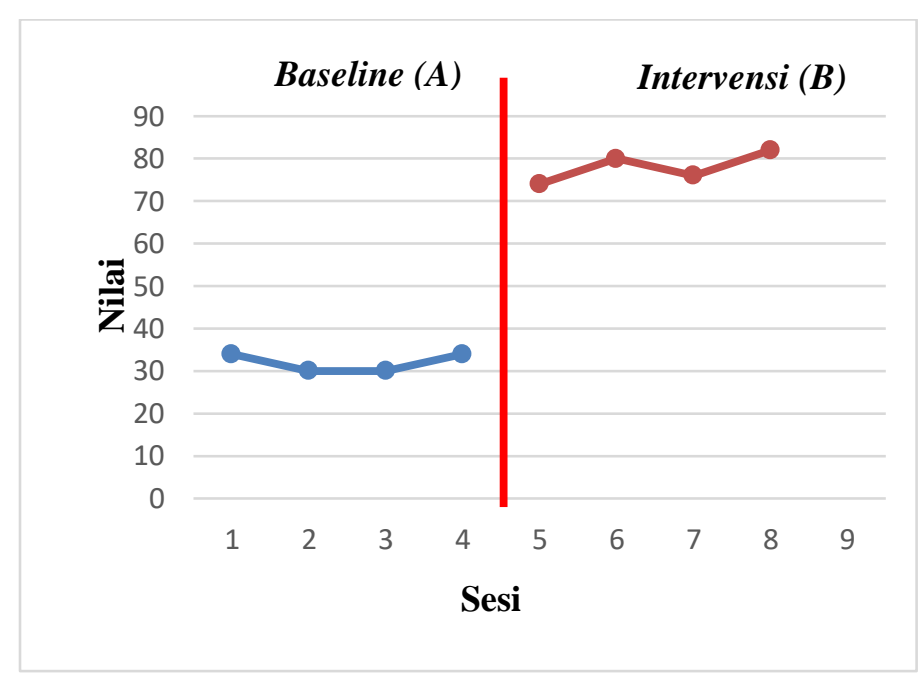

Gambar 3. Penyajian grafik data analisis visual Fase Baseline dan Fase Intervensi 
Berdasarkan data hasil evaluasi tersebut, selanjutnya dianalisis menggunakan analisis dalam kondisi atau analisis data dalam satu kondisi. Hal ini dilakukan untuk mengetahui kondisi awal dari subyek penelitian. Adapun hasil analisis dalam kondisi dapat dilihat pada Tabel 2.

Tabel 2. Rangkuman hasil analisis visual dalam kondisi

\begin{tabular}{|c|c|c|c|}
\hline No & Kondisi & $\mathbf{A}$ & $\mathbf{B}$ \\
\hline 1. & Panjang Kondisi & 4 & 4 \\
\hline 2. & Kecenderungan Arah & & \\
\hline 3. & Kecenderungan Stabilitas & $\begin{array}{c}\text { Stabil } \\
(100 \%)\end{array}$ & $\begin{array}{c}\text { Stabil } \\
(100 \%)\end{array}$ \\
\hline \multirow[t]{2}{*}{4.} & Kecenderungan Jejak & & \\
\hline & & $(=)$ & $(=)$ \\
\hline \multirow{2}{*}{5.} & \multirow{2}{*}{$\begin{array}{l}\text { Level Stabilitas dan } \\
\quad \text { Rentang }\end{array}$} & Stabil & Stabil \\
\hline & & $30-34$ & $74-82$ \\
\hline \multirow{2}{*}{6.} & & $34-30$ & $82-74$ \\
\hline & Pe & $(+4)$ & $(+8)$ \\
\hline
\end{tabular}

Tabel 2 menunjukkan bahwa panjang kondisi atau sesi pada kondisi baseline ada 4 sesi dan kondisi intervensi ada 4 kondisi. Kemudian kecenderungan arah pada fase baseline menunjukan tren yang mendatar artinya terdapat perubahan yang baik namun kurang terlihat, sedangkan fase intervensi menunjukan trend yang meningkat artinya adalah perubahan yang baik dan terlihat. Selanjutnya kecenderungan stabilitas, pada Tabel 4 tersebut dapat dilihat bahwa data di dua fase baik fase baseline maupun intervensi memiliki data yang stabil. Setelah itu, kecenderungan jejak mendatar pada fase baseline yang artinya pada fase baseline data jejak data mengalami perubahan namun tidak kurang terlihat dan pada fase intervensi meningkat. Ini artinya jejak data mengalami perubahan yang terlihat. Rentang stabilitas data pada fase baseline stabil antara 30 hingga 34 dan pada fase intervensi juga stabil antara 74 hingga 82 . Kemudian perubahan level yang menunjukan perubahan data dalam kondisi yang berbeda dengan perubahan data pada fase baseline yaitu +4 dan perubahan data pada fase intervensi yaitu +8 . 
Setelah data dianalisis menggunakan analisis dalam kondisi, kemudian data dianalisis menggunakan analisis antar kondisi. Analisis ini untuk melihat data dalam beberapa kondisi. Komponen yang di analisis hampir sama dengan analisis dalam kondisi hanya saja analisisnya dilakukan bukan melihat satu per satu kondisi tetapi langsung dua kondisi yaitu kondisi baseline dan kondisi intervensi secara utuh (Prahmana, 2021). Adapun hasil analisis antar kondisi dari penelitian ini dapat dilihat pada Tabel 3.

Tabel 3. Rangkuman hasil analisis visual antar kondisi

\begin{tabular}{ccc}
\hline No & Perbandingan Kondisi & $\begin{array}{c}\text { B:A } \\
(\mathbf{2 : 1})\end{array}$ \\
\hline 1 & Jumlah variabel yang dirubah & 1 \\
2 & Perubahan kecenderungan arah dan & \\
efeknya & $(=)$ & $(=)$ \\
3 & Perubahan kecenderungan stabilitas & Stabil ke stabil \\
4 & Perubahan level & $(34-74)$ \\
& & $(+) 40$ \\
5 & Presentase overlap & $0 \%$ \\
\hline
\end{tabular}

Tabel 3 menunjukan bahwa dalam penelitian Single Subject Research ini terdapat satu variabel yang dirubah yaitu pemahaman siswa mengenai materi perbandingan senilai dan berbalik nilai. Kemudian kecenderungan arah pada fase intervensi grafik kecenderungan arahnya meningkat. Ini artinya terdapat perubahan perilaku yang terlihat dan fase baseline mendatar artinya ada perubahan perilaku, namun kurang terlihat.

Selanjutnya, kecenderungan stabilitas yaitu stabil ke stabil artinya data dari fase baseline hingga fase intervensi cenderung stabil. Perubahan level atau perubahan data dari fase baseline, hingga fase intervensi yaitu +40 . Ini artinya ada peningkatan dengan selisih skor 40. Overlap 0\% atau dapat diartikan bahwa data pada penelitian ini tidak ada yang tumpang tindih.

Berdasarkan data hasil evaluasi pembelajaran yang kemudian dianalisis dengan analisis dalam kondisi dan analisis antara kondisi dapat diketahui bahwa terdapat perubahan perilaku berupa meningkatnya pemahaman siswa slow learner dalam memahami materi perbandingan senilai dan berbalik nilai menggunakan pendekatan 
contextual teaching and learning. Hal ini sesuai dengan peneltian sebelumnya, yang menyatakan bahwa pendekatan contextual teaching and learning dapat meningkatkan kemampuan pemahaman matematis siswa (Fatmawati \& Subarjah, 2016). Selanjutnya, Rusyda and Sari (2017) menjelaskan bahwa penerapan model contextual teaching and learning pada pembelajaran garis dan sudut mampu meningkatkan kemampuan konsep matematis siswa. Terakhir, penelitian Sipayung (2018) menunjukkan bahwa pemahaman konsep matematika tentang sifat-sifat bangun ruang sederhana mampu ditingkatkan melalui contextual teaching and learning.

Penelitian ini memiliki kontribusi untuk menambah khazanah ilmu pengetahuan khususnya dalam bidang pendidikan matematika mengenai peningkatan pemahaman matematika siswa menggunakan pendekatan contextual teaching and learning. Selain itu, penelitian ini juga berperan dalam menambah referensi penelitian-penelirian sebelumnya mengenai Single Subject Research dalam pembelajaran matematika, sebagaimana hasil penelitian Ulfah dan Prahmana (2018) mengenai penelitian Single Subject Research tentang implementasi pembelajaran berbasis masalah terhadap pemahaman matematis siswa; Yanti, Prahmana, dan Fitriyah (2018) terkait penelitian Single Subject Research tentang pembelajaran phytagoras pada siswa introvert; Jannah dan Prahmana (2019) mengenai penelitian Single Subject Research tentang pembelajaran pecahan menggunakan konteks sedotan untuk siswa tunarungau; dan penelitian Nuari, Prahmana, dan Fatmawati (2019) mengenai penelitian Single Subject Research tentang pembelajaran operasi pembagian untuk siswa keterbelakangan mental menggunakan matematika gasing.

\section{KESIMPULAN}

Kemampuan siswa sebelum diberi perlakuan mendapatkan skor rata-rata 32 (skala 100). Selanjutnya, skor rata-rata siswa setelah diberi perlakuan berupa pendekatan kontekstual learning menjadi 78 (skala 100). Hal ini menunjukkan bahwa terdapat peningkatan skor kemampuan siswa pada materi perbandingan senilai dan berbalik nilai. Di sisi lain, siswa slow learner mengalami kesulitan belajar karena mempunyai IQ dibawah rata-rata siswa pada umumnya, serta kesulitan pada area perhitungan, kesulitan mengerjakan soal sebelum diberi perlakuan, kesulitan memahami materi, dan lamban dalam menerima materi yang diajarkan. Terakhir, faktor yang mempengaruhi kesulitan belajar matematika siswa slow learner adalah faktor internal yaitu siswa kurang 
konsentrasi saat di kelas, cenderung pasif ketika pelajaran matematika dan faktor eksternal yaitu faktor non sosial.

\section{DAFTAR PUSTAKA}

Abdillah, A., \& Fitriana, F. N. (2019). Penerapan Pembelajaran Matematika Realistik Pada Materi Penjumlahan Bilangan Bagi Siswa Kelas 1 SDN 16 Mataram Tahun 2018/2019. JPIn: Jurnal Pendidik Indonesia, 2(1), 33-40. https://doi.org/10.47165/jpin.v2i1.65

Amir, Z, \& Risnawati. (2015). Psikologi Pembelajaran Matematika. Yogyakarta: Aswaja Pressindo.

Arsjad \& Rizal H. (2013). Pendekatan Kontekstual dalam Pembelajaran (Penerapannya Pada Anak Disabilitas Belajar). Manado: Penerbit STAIN Manado Press.

Elita, S. (2012). Efektifitas Metode Jarimatika dalam Meningkatkan Kemampuan Perkalian Bagi Anak Kesulitan Belajar. Jurnal Ilmiah Pendidikan Khusus, 1(1), 23-34.

Fatmawati, F. F., \& Subarjah, H. (2016). Contextual Teaching and Learning untuk Meningkatkan Kemampuan Pemahaman Matematis Siswa. Jurnal Pena Ilmiah, 1(1), 1071-1080. https://doi.org/10.23819/PI.V1I1.3027

Harahap, D. H., \& Syarifah, R. (2017). Studi Kasus Kesulitan Belajar Matematika pada Remaja. Jurnal Psikologi, 11(1), 21-23.

Harahap, S. Y. (2019). Logika (Vlog Matematika): Solusi dalam Menciptakan Generasi Cerdas dan Berbudaya. Jurnal Equation: Teori dan Penelitian Pendidikan Matematika, 2(1), 46-59.

Haryono, Y. R. (2017). Peningkatan Aktivitas dan Hasil Belajar IPA melalui Kooperatif Tipe Two Stay Two Stray bagi Siswa Kelas VII 1 SMP Negeri 2 Toroh Kabupaten Grobogan Semester Genap Tahun 2015/2016. Manajemen Pendidikan, 12(1), 6072. https://doi.org/10.23917/jmp.v12i1.2976

Herrera, G. C., \& Kratochwill, T. R. (2005). Single-Case Experimental Design. In S. W. Lee (Ed.), Encyclopedia of School Psychology (pp. 501-504). Thousand Oaks, CA: Sage Publications. 
Hidayat. (2009). Model dan Strategi Pembelajaran ABK dalam Setting Pendidikan Inklusif. Workshop "Pengenalan \& Identifikasi Anak Berkebutuhan Khusus (ABK) \& Strategi Pembelajarannya". Balikpapan: Parents Support Group (PSG).

Jannah, A. F., \& Prahmana, R. C. I. (2019). Learning Fraction using the Context of Pipettes for Seventh-Grade Deaf-Mute Student. Journal for the Education of Gifted Young Scientists, 7(2), 299-321.

Kurnia, R. (2020). Upaya Meningkatkan Kemampuan Pemahaman Konsep Matematis Siswa Pada Materi Bentuk Aljabar Melalui Pendekatan Contextual Teaching and Learning Berbantu Alat Peraga di Kelas VII-7 SMP Negeri 18 Tangerang Selatan. Euclid, 7(1), 70-76.

Maylina, R., Sudarti, S., \& Rustiawan, I. (2019). Analisis Kesalahan Siswa Kelas 10 DPIB 1 SMKN 2 Jember dalam Memecahkan Permasalahan Fisika pada Materi Hukum Newton. FKIP e-PROCEEDING, 4(1), 275-279

Muchlis, E. E. (2012). Pengaruh Pendekatan Pendidikan Matematika Realistik Indonesia (PMRI) Terhadap Perkembangan Kemampuan Pemecahan Masalah Siswa Kelas II SD Kartika 1.10 Padang. Exacta, 10(2), 136-139.

Musyafa, M., Warsali, W., Milah, C. S., Aliyudin, A., Supianti, I. I., \& Amam, A. (2020). Pendekatan Contextual Teaching and Learning (CTL) untuk Meningkatkan Pemahaman Matematik Siswa Pada Materi Aritmatika Sosial. Teorema: Teori dan Riset Matematika, 5(1), 69-76.

Neuman, S.B., \& McCormick, S. (1995). Single-Subject Experimental Research: Applications for Literacy. Newark: International Reading Association.

Nuari, L. F., Prahmana, C. I., \& Fatmawati, I. (2019). Learning of Division Operation for Mental Retardations' Student through Math GASING. Journal on Mathematics Education, 10(1), 127-142. https://doi.org/10.22342/jme.10.1.6913.127-142

Prahmana, R. C. I. (2021). Single Subject Research (Teori dan Implementasinya: Suatu Pengantar). Yogyakarta: UAD Press.

Rakhmawati, N. (2017). Kesulitan Matematika Siswa Slow Learner Kelas IV di SD Negeri Batur 1 Semarang. Widia Ortodidaktika, 6(7), 665-677.

Richardo, R., Abdullah, A. A., \& Yuherni, Y. (2018). Identifikasi Kreativitas Siswa Slow Learner dalam Memecahkan Masalah Matematika. De Fermat: Jurnal Pendidikan Matematika, 1(1), 39-45. https://doi.org/10.36277/defermat.v1i1.18 
Rusyda, N. A., \& Sari, D. S. (2017). Pengaruh Penerapan Model Contextual Teaching and Learning Terhadap Kemampuan Pemahaman Konsep Matematis Siswa SMP Pada Materi Garis dan Sudut. JNPM (Jurnal Nasional Pendidikan Matematika), 1(1), 150-162. https://doi.org/10.33603/jnpm.v1i1.243

Saleh, M. H., Huriaty, D., \& Riadi, A. (2017). Pembelajaran Matematika Pada Anak Berkebutuhan Khusus (ABK) Tipe Slow Learners. Math Didactic: Jurnal Pendidikan Matematika, 3(2), 84-92. https://doi.org/10.33654/math.v3i2.58

Sipayung, A. (2018). Meningkatkan Pemahaman Konsep Matematika tentang Sifat-Sifat Bangun Ruang Sederhana melalui Contextual Teaching and Learning. Mosharafa: Jurnal Pendidikan Matematika, 7(3), 401-412.

Sunanto, dkk. (2006). Pengantar Penelitian dengan Subyek Tunggal. Jepang: Universitas Tsukuba.

Tamur, M., Jehadus, E., Nendi, F., Mandur, K., \& Murni, V. (2020). Assessing the Effectiveness of the Contextual Teaching and Learning Model on Students' Mathematical Understanding Ability: A Meta-Analysis Study. Journal of Physics: Conference Series, 1657(1), 012067.

Ulfah, A. F., \& Prahmana, R. C. I. (2018). Single Subject Research: Implementasi Pembelajaran Berbasis Masalah Terhadap Pemahaman Matematis Siswa. Jurnal Elemen, 4(1), 105-118. https://doi.org/10.29408/jel.v4i1.553

Untari, E. (2013). Diagnosis Kesulitan Belajar Pokok Bahasan Pecahan Pada Siswa Kelas V Sekolah Dasar. Jurnal Ilmiah STKIP PGRI Ngawi, 13(1), 1-8.

Yanti, O. F., Prahmana, R. C. I., \& Fitriyah, F. (2018). Single Subject Research: Pembelajaran Phytagoras pada Siswa Introvert Kelas VIII. Beta: Jurnal Tadris Matematika, 11(1), 37-49. 